\title{
ТРУДЫ О ГРАЖДАНСКОМ ПРАВЕ КНР
}

Пащенко Е.Г. Экономическая реформа в КНР и гражданское право. - М., "СПАРК". - 1997;

Пащенко Е.Г. Гражданское законодательство КНР. - М., Международный центр финансово-экономического развития. - 1977.

С точки зрения тематики монография представляет интерес прежде всего в связи с тем, что является первым в отечественной цивилистике сравнительно обширным и углубленным исследованием гражданско-правовой тематики в китайском контексте. Нсследования о китайском праве, надо признать, не являются частым явлением в отечественной юридической науке: о китайском гражданском праве не писалось с начала 60-х годов. И причина этого не в нерадивости либо отсутствии интереса наших правоведов, а в том, что писать было собственно не о чем: всем известно, что собой представляла "культурная революция" и каковы были ее последствия. Появление монографии свидетельствует о возрождении изучения китайского гражданского права в России, о появлении научного направления в отечественной цивилистике.

Об̈ актуальности исследования в свете сказанного выше, думается, не приходится говорить. Знание права нашего ближайшего соседа - Китая - важно как с научной, так и с практической точки зрения. И в данной связи хотелось бы отметить, что монография Е.Г. Пащенко представляет собой работу, основанную на современных китайских источниках, благодаря чему в научный оборот вводится значительное количество нового нормативного материала, который сопровождается критическим анализом взглядов китайских правоведов, занимающихся теоретическим концептуальньм обоснованием юридических аспектов китайской экономической реформы.

Автор монографии видит свою главную задачу в том, чтобы "взглянуть на китайскую экономическую реформу с гражданскоправовой точки зрения", точнее - выявить роль и значение гражданского права в регулировании перестраиваемых экономических отношений в китайском обществе, объяснить основные особенности процесса формирования системы гражданского права КНР, показать специфику основных цивилистических институтов, “обслуживающих" реформируемый хозяйственный механизм (с. 7). Надо признать, с этими задачами автор справился.

Монография привлекает внимание еще в одном отношении. Автор старается раскрыть тему в контексте китайской правовой тради- 
ции, ее влияния на правопонимание и реализацию права на современном этапе жизни китайского общества. Хочется оговориться, что проблема специфики проявления китайской правовой традиции это, безусловно, тема отдельного, специального исследования. В рецензируемой работе скорее делается "заявка" на рассмотрение данной проблемы. Но, тем не менее, такой подход автора оправдан, поскольку позволяет лучше понять особенности правового обеспечения китайской экономической реформы, специфику становления обновляемой системы гражданского права. В частности, верно подмечена особая социально-политическая и экономическая роль государства, которое тысячелетиями господствовало над материальной и духовной жизнью китайского общества.

Это обстоятельство сказывается и поныне, существенно влияя на становление гражданского общества в Китае.

В монографии условно можно выделить "общую" и "особенную" части. $\mathrm{K}$ “общей” части относятся, помимо темы о китайской правовой традиции, также вопросы об особенностях политики китайского руководства в сфере гражданско-правового регулирования, о своеобразии развития гражданского права КНР, объясняемом взаимодействием субъективного и объективного факторов, о влиянии концепции самой реформы, направленной на создание некоего симбиоза плановой и рыночной экономики, на подходы к определению правового статуса субъектов производственно-хозяйственной деятельности, к регулированию договорных форм организации хозяйственных отношений.

Верным представляется подход автора к рассмотрению конкретных сторон хозяйственного механизма через призму проблемы соотношения плановых и рыночных начал в китайской экономике. Благодаря этому удается показать трудности и известные нелогичности в конструировании правового статуса госпредприятия, которое формально наделяется широкой самостоятельностью, но деятельность которого продолжает оставаться под достаточно плотньм государственным контролем и которое, вдобавок, может быть объявлено банкротом (с. 64-84). Автор справедливо указывает (в контексте проблемы "план-рынок") на искусственность так называемой системы подрядно-хозяйственной ответственности директора госпредприятия перед вышестояшим органом хозяйственного руководства, поскольку подобная система представляет собой попытку внедрить договорные средства регулирования в административные отношения (с. 150-160).

Фактически в качестве одного из основных направлений исследования (его тоже можно отнести к “общей” части) выступает анализ отношений собственности в китайской экономике. Данная тема представлена в монографии последовательно и подробно. В резуль- 
тате автору удалось доказать, что китайские реформаторы, несмотря на впечатляющие масштабы реформы, достаточно осторожно подходят к изменению отношений собственности, особенно в государственном и так называемом коллективном секторах экономики. И это, как отмечалось, имеет результатом не только во многом искусственный статус госпредприятия, но и неопределенность в отношениях "коллективной собственности". С одной стороны, в этой собственности продолжают находиться многие мелкие и средние городские и сельские предприятия, обрабатываемые земли. Задаваясь вопросом о том, какие же субъекты хозяйственной деятельности являются носителями права коллективной собственности, в чем специфика этого права, автор проводит тщательный анализ ряда нормативных актов, регламентирующих правовой статус провозглашаемых носителей этого права, и в итоге показывает, что в действительности в массе коллективные предприятия не являются собственниками своего имушества, что правовой статус этих предприятий конструируется с расчетом на возможность подчинения их деятельности государственному регулированию (с. 98). Что же касается земельных отношений, то и в этой сфере вопрос о том, кому принадлежит обрабатываемая земля, остается нерешенным окончательно, что, как отмечается в монографии, является последствием “коммунизации" китайской деревни.

Вопрос о предпринимательской деятельности граждан в период реформы тоже находит свое отражение на страницах монографии. И в этом случае в качестве исходного автор берет вопрос о праве собственности граждан. Показывая, что многие успехи реформы достигнуты благодаря проявлению частнохозяйственной инициативы, автор одновременно обрашает внимание на то, что китайский законодатель "забывает" провести юридическую границу между правом личной (индивидуальной) и частной собственности граждан (в КНР пока воздерживаются от официального признания частной собственности у негосударственных владельцев имущества). В связи с этим положение граждан-предпринимателей в плане отнесения их к "частникам" и "нечастникам" конструируется с помощью искусственного критерия, связанного с количеством наемных рабочих (с. 115).

Интересны разделы монографии, посвященные анализу договорных форм организации экономических отношений в промышленности и сельском хозяйстве. И снова автор показывает, что переход китайской экономики в стадию реформирования выявил немало проблем в данной области. По мере усиления рыночных начал в организации договорных отношений стал необходим пересмотр прежних административных методов их организации. Реформа потребовала новых подходов $\mathrm{K}$ заключению хозяйственных договоров между предприятиями различных форм собственности, между ними 
и гражданами-предпринимателями и т.д. В китайской деревне начало бурными темпами развиваться хозяйствование на подрядных началах. В результате в КНР практически во многом с нуля стало формироваться договорное право. Центральньм актом в этой сфере стал Закон о хозяйственном договоре, который был рассчитан на регулирование как плановых, так и неплановых обязательств, что в результате породило немало вопросов об их целевой направленности, субъектном составе, правовом режиме и т.д. Выдвижение компартией Китая в 1992 году задачи построения "социалистической рыночной экономики" ознаменовалось, в частности, коренным пересмотром данного закона, что, однако, не означало отказа от хозяйственных обязательств, основанных на плане, а фактически свелось к отказу от закрепления правового режима плановых договоров, с одной стороны, и сохранению возможности их использования на основе субъективного усмотрения того или иного государственного органа хозяйственного руководства (с. 143-146). Анализируя содержание пересмотренного закона, автор показывает, что остались нерешенными и многие вопросы, связанные с принципами исполнения договоров, ответственностью за их неисполнение и пр.

Что касается подрядного хозяйствования в китайской деревне, то в монографии показаны как оторванность реформы в сельском хозяйстве от ее законодательного регулирования, так и причины этого. На наш взгляд, автор прав, когда главной причиной отказа китайского законодателя от развернутого регулирования подрядных отношений в деревне называет не столько быстроту возрождения традиционных, привычных для крестьян форм земледелия, сколько использование потенциала обычного права, которым регулировались земельные отношения в деревне в течение веков. Деревня, таким образом, показала реальную потребность основной массы населения Китая в правовом регулировании производственных процессов на уровне закона.

Оценивая монографию Е.Г. Пашенко в целом, нельзя не подчеркнуть ее поисковый, творческий, самостоятельный характер. Работа отличается высоким уровнем научного анализа. Думается, однако, что работа выиграла бы, если бы автор, строя свое изложение, постарался сочетать анализ с примерами из реальной правовой жизни китайского общества, наглядно показывающими отношение китайского населения к праву, закону.

Главный вывод, к которому, вероятно, должен прийти читатель, в том числе причастный $\mathrm{K}$ законотворческому процессу в России, состоит в том, что при создании адекватного регулирования экономических отношений в переходный период необходимо творчески и критически учитывать опьт не только и не столько развитых стран Запада, но и в первую очередь государств, решаюших аналогичные 
задачи, учитывая, в частности, и положение России как крупной евро-азиатской страны.

Уже после подготовки настоящей рецензии вышла в свет еще одна работа Е.Г. Пащенко, которая органично дополняет первую. Речь идет о сборнике принятых в КНР основополагающих гражданско-правовых нормативных актов, подборку и перевод которых на русский язык впервые осуществил Е.Г. Пащенко (Гражданское законодательство КНР. - М., Международный центр финансово-экономического развития. - 1997). Сборник сопровожден содержательной вступительной статьей составителя.

Резюмируя вышеизложенное, можно прийти к выводу, что рецензируемые в настоящем обзоре работы Е.Г. Пащенко займут достойное место в современной российской компаративистике.

А.А. Костин,
профессор МГИМО(У) МИД РФ

Рецензия поступила в редакиио в мае 19982.

\section{НАШЕГО ПОЛКУ ПРИБЫШО}

Научная литература по проблемам международного права пополнилась еще одним журналом "Международное право", созданным юристами-международниками Азербайджана. А создавать новое на уже достаточно "засеянном и перепаханном" поле всегда трудно, так как требует четкого понимания того, чего не хватает и что хотел бы найти в новом издании достаточно искушенный читатель.

Судя по содержанию первого номера, редакция решила для начала привлечь к журналу внимание, отложив вопрос о месте журнала в системе аналогичных изданий на будушее. На подобный вывод наводит не только само содержание первого номера, но и состав авторов, многим из которых еще предстоит получить признание специалистов в области международного права.

Проблемой любого издания была и остается аудитория, на которую ориентируется журнал: либо это широкий круг специалистов, заинтересованных в печатном органе, где бы они могли не только высказывать свои мысли, но и находить как единомышленников, так и оппонентов, либо случайный читатель, которому все равно, что читать, и руководствующийся принципом "покупай толстый журнал сойдешь за умного". В первом случае значение имеет содержание издания, во втором - его внешний вид. Идеальным является сочетание богатого содержания с привлекательньм внешним видом. 